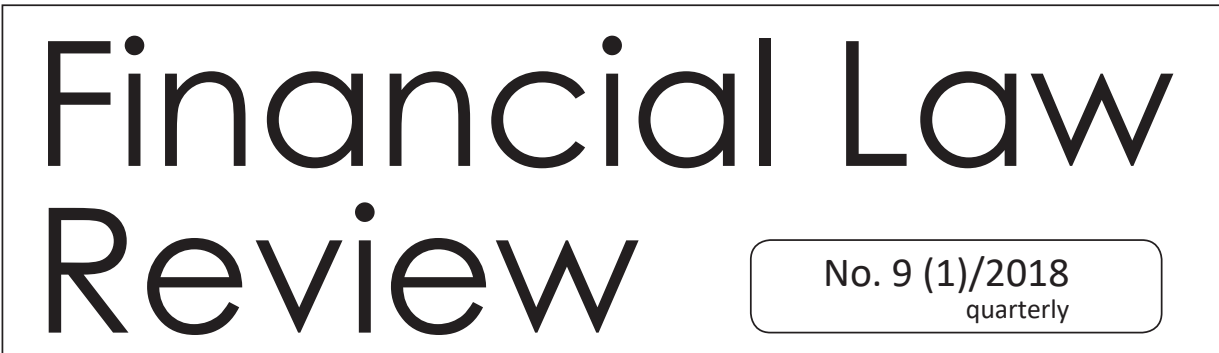

UNIVERSITY OF GDAŃSK • MASARYK UNIVERSITY • PAVEL JOZEF ŠAFÁRIK UNIVERSITY • UNIVERSITY OF VORONEZH http://www.ejournals.eu $\bullet$ http://czasopisma.bg.ug.edu.pl

\title{
DIRECTIONS OF HARMONIZATION IN THE AREA OF DIRECT TAXATION IN THE EURASIAN ECONOMIC UNION ${ }^{1}$ KARINA PONOMAREVA*
}

\begin{abstract}
The article considers the main directions of harmonization in the area of direct taxation in the Eurasian Economic Union (EAEU). Harmonization of direct taxes in the EAEU does not have such a broad legal basis as harmonization of indirect taxes. At the same time, the necessity of harmonization in the area of direct taxation is due to the need to create equal conditions for the implementation of economic activities and to ensure the functioning of the non-discrimination regime in the member states of the EAEU. The article also examines the actions of the EAEU member states on the implementation of the BEPS Action Plan in the national tax legislation.
\end{abstract}

\section{Key words}

tax law, direct taxation, integration, corporate tax, personal income tax, Eurasian Economic Union

\footnotetext{
1 The research was performed with financial support of the Russian fund of fundamental research (RFFI), project Nr. 17-03-50091 "Legal framework of direct taxation in integration communities (the experience of the European Union and of the Eurasian Economic Union)".

* PhD in Law, Assistant Professor for Financial Law, Department of State and Municipal Law, Faculty of Law, F.M. Dostoevsky Omsk State University, Russian Federation. Author specializes in tax law and public finance. She is the author of 5 books and more than 60 reviewed articles in prestigious journals. Contact email:karinaponomareva@gmail.com
} 
JEL Classification: https://www.aeaweb.org/jel/guide/jel.php

\section{Introduction}

The main directions of harmonization in the area of direct taxation in the Eurasian Economic Union (EAEU) are considered in the article.

The author uses methods of theoretical analysis, particularly the theory of integrative legal consciousness, as well as legal methods, including formal legal method and comparative law.

The scope of the study is closely connected to the following evaluation problems: tax sovereignty, effects of the major recent tax policy initiatives for the Union and Member States, as well as ways of tax harmonization in the EAEU.

Unlike indirect taxes, direct taxes do not have such a tangible impact on pricing and amount of trade between the states. At the same time, the necessity of harmonization in the field of direct taxation is due to the necessity of creation of equal conditions of economic activity and of ensuring of functioning of the non-discrimination regime in the EAEU Member States: different levels of tax burden increase tax competition of Member States and lead to tax optimization through artificial redistribution of funds.

The analysis of the tax legislation of EAEU Member States showed significant achievements in the area of tax administration. However, the measures on implementation of these improvements differ, which will undoubtedly increase the burden of compliance by transnational companies operating in the Union.

The ways and perspective of implementation of BEPS Action Plan in the EAEU and in EAEU Member States are brought into light. The perspective directions of activities of the Eurasian Economic Commission on the way of implementation of BEPS Actions are analysis of the tax legislation of the Member States; development of strategic approaches to the taxation regime of cross-border e-commerce on the EAEU level; coordination of the creation of uniform rules of transfer pricing in the Member States; exchange of tax information; exchange of experience on the application of DTTs within the Union.

The author comes to the conclusion that the EAEU Treaty and other supranational acts show the limits of tax harmonization: this is mainly indirect taxation, in particular, the establishment of principles of collection of indirect taxes in Member States, the establishment of a general list of excisable goods, harmonization 
(convergence) of excise rates for the most sensitive excisable goods, and in the part of direct taxation there is principle of non-discrimination in the area of taxation of personal income. At the national level, Member States have set the same taxes, including corporate income tax and personal income tax. Corporate tax rates are flat in all five countries. However, in the absence of supranational tax acts (like EU directives) national tax systems differ significantly: the elements of the composition of taxes and their role in the structure of the revenues of national budgets differ. This is caused by the fact that the area of direct taxation is highly sensitive from the positions of tax sovereignty of Member States.

\section{Chapter 1}

Harmonization of direct taxes in the Eurasian Economic Union (hereinafter - the EAEU) does not have such a broad legal basis as the basis of harmonization of indirect taxes. The political will to harmonize indirect taxes, in contrast to direct taxes, was quite accurate. The long-term goal of harmonization of indirect taxes is the creation of both customs union, and internal market. At the same time, the competence in the field of taxation is delineated between Member States and does not establish legal or material boundaries for participants of the common market.

According to the norms of Articles 3 and 5 of the EAEU Treaty the Union shall have jurisdiction within the scope and limits determined under the Treaty and international treaties within the Union. The Member States shall carry out coordinated or agreed policy within the scope and limits determined under this Treaty and international treaties within the Union.

In areas related to a unified policy, Union bodies adopt acts which are binding for Member States but can be disputed in the EAEU Court upon application of legal entities and individuals whose rights and interests have been violated by such acts.

Unlike indirect taxes, direct taxes do not have such a tangible impact on pricing and amount of trade between the states, however, differences in the amount of rates, the procedure of formation of the tax base and the list of tax exemptions can create unequal conditions of economic activity in EAEU Member States and lead to significant differences in the investment attractiveness of these countries (Ponomareva, 2017: 74). At the same time, the necessity of harmonization in the area of direct taxation is due to the necessity of creation of equal conditions of economic activity and of ensuring of functioning of the non-discrimination 
regime in the EAEU Member States: different levels of tax burden increase tax competition of Member States and lead to tax optimization through artificial redistribution of funds.

The transition to a new phase of Eurasian economic cooperation, when the Eurasian Economic Union has replaced the Customs Union, makes it necessary to take a fresh look at the problems of harmonization and unification of the tax legislation in Member States.

Integration law cannot go beyond the necessary regulation in order to ensure the functioning of the internal market, but at the same time it must solve integration problems. It is obvious that there are no Union taxes in the EAEU, as well as in the European Union (hereinafter referred as the EU): taxes are in the competence of the Member States, taxes are established by tax codes and are being collected by national tax authorities. To date, taxation is not the most important political tool, but we believe that in the near future its role will increase: according to Kozyrin, "the influence of tax legislation and foreign economic relations are mutual” (Kozyrin, 2015: 34.).

The EAEU Treaty has repeatedly mentioned the harmonization and unification of legislation as means of achieving the goals of the Union, in particular, the creation and maintenance of the functioning of the internal market. According to Article 2 of the EAEU Treaty, the harmonization of legislation means the approximation of legislation of the Member States aimed at establishing similar (comparable) legal regulations in certain spheres; unification of legislation means the approximation of legislation of the Member States aimed at establishing identical mechanisms of legal regulation in certain spheres as specified in this Treaty.

The researchers note that it is obvious that the desire for a consistent harmonization of the legislation of different states, the generalization of their legislative approaches and the definition of a single line of international cooperation is expressed in the form of an international treaty that consolidates approaches on any important subject of cooperation" (Lukianova, 2012).

Harmonization and unification are interrelated but they are not coincidental. Harmonization is a broader concept and can be implemented through unification as well as through other means. In turn, the unification of national models of tax legislation implies such a convergence, in which the states participating in this process assume certain international obligations. The unification of law in the broad sense does not aim to remove differences in the legal regulation 
of similar relations in the law of individual states, creating uniform rules of law, but aims to remove obstacles on the way of international cooperation. For example, although the tax rates for personal income tax in Member States are different, we believe that their unification is not required.

Ever since the existence of Eurasian Economic Community (hereinafter EurAsEC), the following models of convergence of national legislations have developed:

1. Conclusion of an international treaty. After the expression of the recognition of the binding nature of the international treaty provisions by all participating States it is legally binding for all contracting parties, bodies and officials of these States.

2. Adoption of model laws. Model laws have been disseminated in EurAsEC, they are not legally binding but contain provisions of a recommendatory nature addressed to Member States. Examples of such acts are the Fundamentals of the tax legislation of the EurAsEC Member States and the Recommendations on harmonization of the main provisions of the tax legislation of the EurAsEC Member States, prepared on the basis of a comparative legal analysis of national legislations.

Kucherov points out that "the implementation of the norms of the model legislative act is possible in the form of approval and adoption (with possible adjustment) of the text of the model law as an act of national legislation; making amendments and additions to the acting acts, i.e. "inclusion" of certain rules of the model act in the existing regulatory legal acts of the state; "incorporation" of the norms of the model act into national legislation and the adoption by the parliament of its own regulatory legal act on the basis of a model act (Kucherov, 2015).

"Model tax laws have been adopted for a sufficiently long time within the framework of the Commonwealth of Independent States (hereinafter - CIS). However, the EAEU and the CIS are interstate unions with different goals, and within the CIS the integration of states has reached the level of the free trade zone. 11 chapters of the Model Tax Code have been adopted during the period from 2001 to 2015. The last one became the General Part, work on which required a higher level of generalization of the legislation and practice of Member States. The aim of the General Part of the CIS Model Tax Code is to provide a framework for common approaches to the creation of legal and organizational mechanisms for tax systems, for example, its previous version was actively used in drafting 
tax laws in Belarus, Kyrgyzstan, Tajikistan, and a number of its provisions were included in the Tax Code of Kazakhstan. Some explanations of the Ministry of Finance of Russia contain references to the General Part of the Model Tax Code. We believe that the norms of "soft" law, such as the provisions of model acts, can be applied in cases they offer better or new solutions in comparison with those available in the current legislation of the Member States. It can be concluded that the inclusion in the Model Tax Code of provisions based on the experience of the EU and OECD will create a basis for harmonizing the tax legislation of EAEU Member States.

3. The use of the method of unification in the framework of the adoption of a uniform act of an interstate association, often referred to as the code of interstate association, but in contrast to international legal unification having features of direct supranational character. This model takes place at the "advanced" stages of cooperation of states, that is, in the presence of established deep ties between the member states of the integration association. An example of such an act is the Customs Code of the EAEU (The Treaty of Customs Union and Single Economic Space of February 26, 1999 http://evrazes.com/docs/view/128)

Currently, the greatest amount of work on harmonization and unification falls on the income tax and personal income tax. The main ways of harmonization are the unification of terminology (especially this refers to the name of income tax in different Member States); unification of the methodology for the formation of the tax base; consideration of the issue of unification of tax rates (we believe that there is no need for such unification).

The tax legislation of EAEU Member States has a common historical basis, which caused similar features of the tax legislation of the states that borrowed basic principles from the Soviet legislation. The common features of the heritage are adherence to the codification of tax legislation, a high degree of fiscal centralization, as well as an essential role of the executive in the field of taxation. Different rates of income tax and personal income tax in EAEU Member States are explained by the unequal level of economic development, the specifics of the tax policy of each state and the course of tax reforms. The formation of the EAEU tax law includes not only the rules regulating the harmonization of tax systems of member states, it is supplemented by new norms in connection with the development of cooperation between the tax authorities of the Member States. Over the past 20 years current Member States of the EAEU have signed and ratified a number 
of international treaties governing the interaction between the tax authorities of the Member States.

The exchange of information is an obligatory element of tax administration. Since taxpayers have gone beyond the borders of their countries, the exchange of information between the tax services of Member States is highly relevant. In this regard, the Working Group on Information Exchange among the Tax Authorities of the CIS Member States has invited tax services to consider a draft Protocol on the exchange of information in electronic form between the tax authorities of the CIS Member States for tax administration and the drafts of the information exchange procedures attached to it: for individual types of income of legal entities which are tax residents of CIS member states, for individual types of income of individuals who are tax residents of the CIS countries, of certain types of property located on the territory of the participating States and their owners. By the order of the Government of the Russian Federation of August 12, 2017 No. 1728-r "On the signing of the Protocol on the exchange of information in electronic form between the tax authorities of the CIS member states for implementation of tax administration" the proposal of the Ministry of Finance of Russia, agreed with the Ministry of Foreign Affairs of Russia and the Federal Tax Service of Russia, on signing the Protocol on the exchange of information in electronic form between the tax authorities of the participating CIS States for the implementation of tax administration has been accepted (The official Internet portal of legal information: http://www.pravo.gov.ru, 15.08.2017).

Article 68 (1) of the EAEU Treaty provides the duty of the Member States to assist each other in ensuring effective cooperation between the competent authorities on matters governed by section XV of the Treaty. To ensure the effectiveness of cooperation, including the exchange of information, the competent authorities of member states are obliged to conclude agreements. Thus, the exchange of information for tax purposes between EAEU Member States has been working for quite a long time.

In recent years, the actions of states and international organizations in the field of taxation of profits and revenues are linked to the Action Plan on Base Erosion and Profit Shifting (hereinafter - the BEPS Action Plan, OECD Action Plan on Base Erosion and Profit Shifting // OECD Publishing: http://dx.doi. org/10.1787/9789264202719-en), and implementation of its individual actions. The Eurasian Economic Commission is working on analyzing the activities carried out by the Member States to implement the BEPS Action Plan. During 
the elaboration of the actions of the BEPS Action Plan it was determined that the minimum standards, that is, the implementation of Actions 5, 6, 13, and 14 are mandatory for implementation in the OECD and G20 Member States. During the second regional meeting for the Eurasian region on Base erosion and profit shifting in October 2015 the OECD representatives stressed out that countries wishing to implement the principles of the BEPS Action Plan are not obliged to implement all the Actions. The implementation should take into account the characteristics of the national economy and foreign economic activity. Based on this, it is possible to choose Actions and tools of their implementation that, in conditions of limited resources, will maximize the ability to resist tax abuse in each country and will fit in with specific features of the environment and business.

Action 15 of the BEPS Action Plan indicates the need to develop a multilateral instrument for avoiding double taxation. The BEPS plan provides national governments with the possibility of closing gaps that dilute the tax base and reduce the corporate tax burden to zero. On June 7, 2017, a new instrument to combat such phenomena appeared: 68 countries signed the OECD Multilateral Convention to Implement Tax Treaty Related Measures to Prevent Base Erosion and Profit Shifting (hereinafter - MLI). The Russian Federation and the Republic of Armenia joined the MLI. The EAEU Member States are not OECD participants, therefore most of the OECD documents are of a recommendatory nature for them. Meanwhile, EAEU Member States are planning to implement or are working on the implementation of a number of BEPS Actions with regard of national peculiarities.

Thus, the Republic of Armenia is considering becoming an associate member of the BEPS project. The Republic of Armenia has developed a draft law that provides for the introduction of transfer pricing rules (Actions 8, 9, 10 and 13), and thin capitalization rules have been introduced.

The Republic of Belarus cooperates with the OECD. The OECD Model Convention on Income and Capital (hereinafter referred to as the OECD Model) is the basis for the negotiation and conclusion of double tax treaties (hereinafter - DTT) by the Republic of Belarus. When interpreting the provisions of tax agreements, the Republic of Belarus adheres to the principles set out in the Commentaries to the OECD Model. At the same time, the Republic of Belarus is neither a member nor an observer of the OECD, as a consequence of which the OECD documents are not part of the Belarusian legislation and are not legally binding for Belarus. At the same time, the Tax Code of the Republic of Belarus is supplemented with 
provisions aimed at preventing the withdrawal of profits within the framework of the fine capitalization mechanism; since January 1,2016, the rules of transfer pricing have been supplemented and improved, and the provisions of the legislation establishing the right of tax authorities to request from a non-resident receiving the income documents have been extended to determine whether it is the true owner of income received from sources in the Republic of Belarus.

It is planned in the Republic of Kazakhstan that after the completion of the work on the analysis of the BEPS Action Plan the tax legislation will be amended. Work in this direction, including on leadership and intersectoral coordination in the field of countering the legalization of proceeds from crime, will be conducted by the Ministry of Finance of the Republic of Kazakhstan.

4. Since January 1, 2018, the new Code of the Republic of Kazakhstan on taxes and other mandatory payments to the budget (the Tax Code) has been enacted (the Code of the Republic of Kazakhstan about taxes and other obligatory payments on budget (Tax code) from December 25, 2017 of No. 120-VI).

The next recommendations of the OECD are interesting for the RC:

- CFC rules,

- thin capitalization,

- elimination of double non-taxation,

- prevention of artificial avoidance of the status of a permanent establishment,

- introduction of a three-level reporting system for transfer prices.

President N.Nazarbayev in his Address to the People mentioned the importance of cooperation with OECD within the framework of the Third Modernization of the RK. Kazakhstan is an active member of the Inclusive Framework on BEPS, which brings together 108 countries and jurisdictions to tackle international tax avoidance. The OECD plans to assist Kazakhstan to implement the BEPS package with a focus on $\mathrm{CbCR}$ and the other minimum standards.

The Kyrgyz Republic is studying the BEPS plan.

The Russian Federation is the most active Member State on the way on implementation of the BEPS plan. Russian results of BEPS Action Plan can be shortly represented as follows: 
- VAT of $18 \%$ for foreign companies selling online electronic content to Russian users - Action 1

- While developing the CEC rules, some recommendations of the BEPS Plan have already been taken into account - Action 3

- The mechanism of "thin capitalization" has been introduced - Action 4

- Amendments to the Model DTT between the Russian Federation and foreign states are going to be made - Action 6

- Clarification of transfer pricing rules in accordance with the recommendations of the OECD - Actions 8, 9, 10

- On January 26, 2017, the Federal Tax Service of Russia signed a multilateral agreement of the competent authorities on the automatic exchange of country reports; the Federal Law of November 27, 2017 No. 340-FZ has been adopted - Action 13

- Participation in meetings of the Forum on Mutual Agreements - Action 14

- The Russian Federation has signed MLI - Action 15

The Eurasian Economic Commission is currently analyzing the legislation of the EAEU Member States, the feasibility of implementing the BEPS plan in the territory of the EAEU, as well as documents adopted within the framework of international associations, with a view to developing proposals for the following directions:

- on uniform rules of transfer pricing in relation to controlled transactions;

- on uniform approaches to the mechanism of confirming of the market nature of pricing in controlled transactions by taxpayers;

- on the establishment of an exchange of financial information between the tax authorities in accordance with OECD standards.

\section{Conclusions}

On the basis of a comparative study of supranational sources and tax legislation of the Member States EAEU the following conclusions can be made:

1. The analysis of the legal acts of the Union and of Member States' legislation showed commonality in the structures of tax systems, development processes 
and the main directions of the tax policy, as well as the specifics of conducting of cross-border transactions. Legislative base of the regime of direct taxation in all Member States is formed and fixed by normative legal acts (tax codes). Taxpayers and elements of taxation are largely identical. However, the coverage of tax harmonization in the field of direct taxation remains very "modest". Tax systems show convergence of legislation on direct taxes, which have a common structure but show a significant number of technical differences.

2. The EAEU Treaty and other supranational acts show limits of tax harmonization: this is mainly indirect taxation, in particular, establishment of principles of collection of indirect taxes in Member States, establishment of a general list of excisable goods, harmonization (convergence) of excise rates for the most sensitive excisable goods, and in the part of direct taxation there is a principle of non-discrimination in the area of taxation of personal income. At the national level, Member States have set the same taxes, including corporate income tax and personal income tax. Corporate tax rates are flat in all five EAEU countries. However, in the absence of supranational tax acts (like EU directives) national tax systems differ significantly: the elements of the composition of taxes and their role in the structure of the revenues of national budgets differ.

3. The process of convergence of tax systems can transform into tax competition if one of the jurisdictions is more actively trying to attract investors through fiscal reforms. The state can follow the same directions of the tax policy as its neighbours by increasing its competitiveness in general (for example, Armenia Development Strategy) or the development of certain policies, for example, in the area of taxation. However, today we can only talk about the rudiments of tax competition, which practically, as mentioned by Tiutiuriukov, exists only between the Russian Federation and Kazakhstan for SME, apparently due to sharing long and open land border, as well as lack of language, cultural and customs barriers (Tiutiuriukov, 2017: 128).

4. The tax legislation and official acts on the tax policy of Member States practically do not indicate obligations within the framework of the Union or other aspects of international cooperation, therefore each state pursues its own taxation objectives. As a few examples of establishing such obligations, the following can be named. Armenia points to the need to improve the competitiveness of the national tax system. The creation of equal conditions for business in the EEA member states is stated in the Main Directions of the Tax Policy of the Russian Federation for 2016 and the Planning Period of 2017 and 2018. In the member 
states, there were no unified requirements for program tax documents: thus, Armenia and the Kyrgyz Republic develop tax programs within the framework of the general economic strategy, Belarus does not publish any plans, although they are available for internal use, in Kazakhstan the President sets strategic goals, and the Government and the Central Bank prepare short-term plans every few years, Russia prepares the main directions of the tax policy every year for a threeyear period. Only in Russia the Ministry of Finance reports on implementation of the tax policy into the tax system on an annual basis (within Main directions of tax policy), whereas in other countries the officers of the tax authorities report on the implementation on ad hoc basis, usually at round tables or during interviews (Tiutiuriukov, 2017: 124).

5. The analysis of the tax legislation of the EAEU Member States showed significant achievements in the field of tax administration. However, the measures on implementation of these improvements differ, which will undoubtedly increase the burden of compliance by transnational companies operating across the Unon. This inconsistency in approaches towards tax policy demonstrates unwillingness of Member States to harmonize tax systems and even deepens the differences between these systems. At the same time, reducing the burden on compliance with legal norms can contribute to the competitiveness of the EAEU as an economic bloc. Complete harmonization in the field of direct taxation is hardly achievable and necessary: different tax systems have been established in the member states, different systems and levels of distribution of tax authorities have been established, the tax authorities have different structures. However, the convergence of reporting rules, the exchange of tax information and tax administration seem quite achievable, especially for centrally administered taxes.

6. Ideas on the need to reduce tax barriers and the objectives of tax harmonization have a limited legislative base in EAEU Member States. At the level of the EAEU and its predecessors, commitments have been made in only a few areas, mainly in the area of indirect taxation, as well as in the area of personal income taxation. Tax systems show signs of convergence of legislation in the structure of tax systems and tax administration rules. Tax competition is also seen only at a very general level, for example, in terms of tax rates, the taxation of non-residents, as well as SME taxation.

7. At the present stage of economic integration of the EAEU, which aims to create an internal market and to ensure fundamental freedoms, it is preferable to use the following forms of tax harmonization: adoption of model legislation, 
mutual consideration of legislative experience of the Member States, implementation of OECD provisions into national tax legislation, in particular, the OECD Conventions and BEPS Action Plan, the development of a concept for improving tax legislation and the formation of law enforcement practices in the Member States. Thus, the EAEU is aimed at the convergence of national legal systems with regard to the functioning of the EAEU purposes.

8. The perspective directions of activities of the Eurasian Economic Commission on the way on implementation of BEPS Actions are analysis of the tax legislation of the Member States; development of strategic approaches to the taxation regime of cross-border e-commerce on the EAEU level; coordination of the creation of uniform rules of transfer pricing in the Member States; exchange of tax information; exchange of experience on the application of DTTs within the Union.

\section{References}

Action Plan on Base Erosion and Profit Shifting OECD Action Plan on Base Erosion and Profit Shifting [электронный ресурc] // OECD Publishing: http://dx.doi. org/10.1787/9789264202719-en

Eurasian Economic Commission. The Protocol on Exchange of Electronic Information between Tax Authorities of the CU Member-States on Indirect Taxes Paid http://eurasiancommission.org/en/nae/news/Pages/08-10-2014-3.aspx

Kozyrin A.: Kodifikacia nalogovogo zakonodatelstva v gosudarstvah Evraziiskogo ekonomicheskogo soyuza (Codification of tax legislation in the states of the Eurasian Economic Union), Reformy I pravo (Law and reforms) no. 4 (2015).

Lukianova, V.Yu. ed.: Pravovye problemy formirovaniya mezhgosudarstvennych obiedinenii (na primere zony svobodnoi torgovli I Tamozhennogo soyuza EvrAseC) (Legal issues of formation of integration communities (Free Trade zone and EurAseC Customs Union as examples), 2012.

Mambetaliev N.T.: Realizacia Plana BEPS v gosudarstvah-chlenah Evraziiskogo ekonomicheskogo soyuza (Implementation of BEPS Action Plan in Member States of the Eurasian Economic Union), Nalogovyi vestnik (Tax Herald) no. 9 (2016).

Multilateral Convention to Implement Tax Treaty Related Measures to Prevent Base Erosion and Profit Shifting // http://www.oecd.org/tax/treaties/multilateral-convention-to-implement-tax-treaty-related-measures-to-prevent-BEPS.pdf

Ponomareva K.: Tax Law of the Eurasian Economic Union: Substance and Ways of Using of the European Experience, EC Tax Review Vol. 25, no 2 (2016).

Ponomareva K.: VAT as an object of harmonization of tax law of the Eurasian Economic Union (a comparative legal issue), Russian Law: Theory and Practice no. 1 (2016).

Ponomareva K.: Napravleniya garmonisacii nalogooblozheniya pribyli i dohodov v Evrasiiskom ekonomicheskom soyuze (Ways of harmonization in the area of taxation 
of income in the Eurasian Economic Union), Vestnik Omskogo universiteta. Seria "Pravo", no. 3 (2017).

Tax Code of the Russian Federation Part One No. 146-FZ of July 31, 1998; Part Two No 117-FZ of August 5, 2000.

Tax Code of the Republic of Belarus (General Part \& Special Part, as amended up to Law of the Republic of Belarus No. 96-3 of December 31, 2013).

Tax Law of the Eurasian Economic Community: the Legal Regime for VAT. D.V. Vinnitskiy (eds.). Moscow, Wolters Kluwer, 2010.

Tiutiuriukov V.: Tax systems in EAEU region: tax harmonisation, tax competition? Doctoral thesis, Brno, 2017.

The Code of the Republic of Kazakhstan about taxes and other obligatory payments on budget (Tax code) from December 25, 2017 of No. 120-VI.

The OECD Model Convention on Income and Capital Model Tax Convention on Income and on Capital: Condensed Version 2014, OECD Publishing // http://dx.doi. org/10.1787/mtc_cond-2014-en

The Treaty of Customs Union and Single Economic Space of February 26, 1999 http:// evrazes.com/docs/view/128

Treaty on the Eurasian Economic Union signed on May 29, 2014 // Official page of the Eurasian Economic Commission <www.eurasiancommission.org > 05.06.2014. 